\title{
Protective paints from natural resources: composition and properties
}

\author{
Szymon Kugler ${ }^{1), *)}$ (ORCID ID: 0000-0003-1301-4578), Paula Ossowicz-Rupniewska ${ }^{1)}$ (0000-0002-2362-1809), \\ Ewa Wierzbicka ${ }^{2)}(0000-0002-9332-8317)$, Jakub Lopiński ${ }^{1)}$
}

DOI: dx.doi.org/10.14314/polimery.2021.7.4

\begin{abstract}
Climate changes and increasing cost of non-renewable resources cause the growing interest in technical materials prepared from natural resources. To meet this interest, prototype paints from rosin and bio-diols derivatives, and also halloysite, were formulated to check their thermal, mechanical, visual and functional properties, as protective coatings of steel. Prepared materials contained ca. $75 \mathrm{wt} \%$ of natural resources and exhibited considerably better corrosion protection, thermal stability, and also higher glass transition temperatures and hardness, than a commercial petroleum-based reference sample. The other parameters: cross-linking behavior, color, gloss, cupping resistance, adhesion and chemical resistance were within the range that is acceptable for potential users.
\end{abstract}

Keywords: bio-diol, halloysite, powder paint, rosin.

\section{Farby ochronne z surowców naturalnych: kompozycja i właściwości}

Streszczenie: Zmiany klimatyczne i rosnące koszty surowców nieodnawialnych powodują zwiększenie zainteresowania materiałami o znaczeniu technicznym, otrzymywanymi z surowców pochodzenia naturalnego. Wychodząc naprzeciw temu zainteresowaniu, opracowano prototypowe farby z pochodnych kalafonii i bio-dioli oraz haloizytu w celu sprawdzenia ich właściwości termicznych, mechanicznych, wizualnych i funkcjonalnych, jako powłok ochronnych dla stali. Przygotowane materiały zawierały ok. 75\% mas. surowców naturalnych i wykazywały znacznie lepszą ochronę przed korozją, stabilność termiczną, a także wyższe temperatury zeszklenia i twardość niż komercyjna próbka referencyjna otrzymana z surowców ropopochodnych. Pozostałe parametry: kinetyka sieciowania, kolor, połysk, tłoczność, adhezja i odporność chemiczna, mieściły się w akceptowalnym zakresie dla potencjalnych użytkowników.

Słowa kluczowe: bio-diol, haloizyt, farba proszkowa, kalafonia.

Global annual demand of paints and coatings will reach 63000000 tons soon [1], i.e. $12-15 \%$ of global polymers production estimated at 438000000 tons in 2017 [2]. In the 20s of the XXI century, the leading research/development challenge for this large and stable market is to meet the increasingly common requirements of circular economy, green chemistry and carbon neutrality in the most important regions of the world [3]. Powder coatings are the class of coating materials, that have the greatest potential to meet the aforementioned requirements. These one-component fine powders excellently protect

\footnotetext{
1) West Pomeranian University of Technology in Szczecin, Faculty of Chemical Technology and Engineering, Department of Chemical Organic Technology and Polymeric Materials, Piastów 42, 71-065 Szczecin, Poland.

2) Łukasiewicz Research Network - Industrial Chemistry Institute, Rydygiera 8, 01-793 Warsaw, Poland

*) Author for correspondence: Szymon.Kugler@zut.edu.pl, Szymon.Kugler@gmail.com
}

steel substrates after application via electrostatic spraying and curing at elevated temperatures. Epoxy/polyester systems constitute the vast majority of powder paints production $[4,5]$. The most burning issue in the field of these materials is the need of possibly the cheapest and, simultaneously, highest-performance products causing the minimal carbon trace. Expectations related to the implementation of the carbon-neutral economy in US, China and EU by 2050 together with the formal obstacles and increasing costs for paint producers, forced them to seek biobased alternatives [6-10].

Such an alternative is rosin: a cheap, abundant and nontoxic raw material, which can be easily converted into many valuable chemicals, including solid epoxy resins and hardeners [11]. The rigid diterpene structure can give them considerably better thermal, mechanical and functional properties in comparison with the other biobased counterparts [8-10,12-16]. Although there is a number of basic studies on rosin-derived components [17-29] curable in epoxy-ring-opening reactions, to the best of our 
$\mathrm{T}$ a b 1 e 1. Symbols and composition of prepared coatings and reference samples

\begin{tabular}{|c|c|c|c|c|c|c|}
\hline \multirow[b]{2}{*}{$\begin{array}{l}\text { Sample } \\
\text { symbol }\end{array}$} & \multicolumn{6}{|c|}{ Weight ratio of components in coating composition (wt. part) } \\
\hline & $\begin{array}{c}\text { Decylene } \\
\text { dimaleopimarate } \\
\text { (DDR) }\end{array}$ & $\begin{array}{l}\text { Poly(decylene } \\
\text { maleopimarate) } \\
\text { (PRD) }\end{array}$ & $\begin{array}{c}\text { Triglycidyl } \\
\text { maleopimarate } \\
(3 \mathrm{GR})\end{array}$ & $\begin{array}{c}\text { Modified } \\
\text { halloysite }(\mathrm{H})\end{array}$ & Titania (P1) & Zinc oxide (P2) \\
\hline $\mathrm{DDR} / 3 \mathrm{GR}^{\mathrm{a})}$ & 61 & - & 29 & - & - & - \\
\hline $\mathrm{DDR} / 3 \mathrm{GR} / \mathrm{H}^{\mathrm{a})}$ & 61 & - & 29 & 2,5 & - & - \\
\hline $\mathrm{DDR} / 3 \mathrm{GR} / \mathrm{P}$ & 61 & - & 29 & - & 3 & 7 \\
\hline $\mathrm{DDR} / 3 \mathrm{GR} / \mathrm{H} / \mathrm{P}$ & 61 & - & 29 & 2,5 & 3 & 7 \\
\hline $\mathrm{PRD} / 3 \mathrm{GR}^{\mathrm{b})}$ & - & 65 & 35 & - & - & - \\
\hline $\mathrm{PRD} / 3 \mathrm{GR} / \mathrm{H}^{\mathrm{b})}$ & - & 65 & 35 & 2,5 & - & - \\
\hline PRD/3GR/P & - & 65 & 35 & - & 3 & 7 \\
\hline $\mathrm{PRD} / 3 \mathrm{GR} / \mathrm{H} / \mathrm{P}$ & - & 65 & 35 & 2,5 & 3 & 7 \\
\hline $\mathrm{COMM}^{\mathrm{c}}$ & - & - & - & - & n.d.a. ${ }^{\text {d) }}$ & n.d.a. ${ }^{\text {d) }}$ \\
\hline
\end{tabular}

a) Reference samples with rosin dianhydride [30].

b) Reference samples with rosin polyester [31].

c) Commercial petroleum-based reference coating.

d) No data available.

knowledge, no prototype of ready powder coating product has been prepared so far.

The aim of this study is to demonstrate prototypes of powder coating systems prepared from natural resources: rosin-biodiol (poly)esters, rosin-sourced epoxy resin, halloysite, and also anticorrosive pigments. The prototypes should be characterized by flow temperatures of $<120^{\circ} \mathrm{C}$ accompanied with properly higher effective curing temperatures $\left(>140^{\circ} \mathrm{C}\right)$, that allows for: (i) production of paints via extrusion process, (ii) application in powder form at room temperature on steel substrates, and (iii) curing process in typical industrial conditions $\left(>140^{\circ} \mathrm{C}\right.$ at normal pressure). This demonstration includes syntheses of components, preparation of coating compositions and coatings and evaluation of their thermal, mechanical and functional properties in comparison with commercial petroleum-based reference sample.

\section{EXPERIMENTAL PART}

\section{Materials}

The following materials were used without further purification:

Rosin-derived decylene-1,10-dimaleopimarate anhydride resin (Fig. 1), light brown solid, acid number 250 $265 \mathrm{mg} \mathrm{KOH} / \mathrm{g}$, softening point $\leq 110^{\circ} \mathrm{C}$ prepared in a process described in our previous work [30]. Rosin-derived poly(decylene maleopimarate) carboxylic resin (Fig. 1), brownish solid, acid number 180-190 mg KOH/g average degree of polymerization $\leq 5$, softening point $\leq 120^{\circ} \mathrm{C}$ prepared in a process described in our previous work [31]. Rosin-derived triglycidyl maleopimarate epoxy resin (Fig. 1), yellowish solid, softening point $70-73^{\circ} \mathrm{C}$, epoxy equivalent weight $299-362 \mathrm{~g} \cdot$ equiv $^{-1}$ prepared in a process described in our previous work [30]. Halloysite, filled

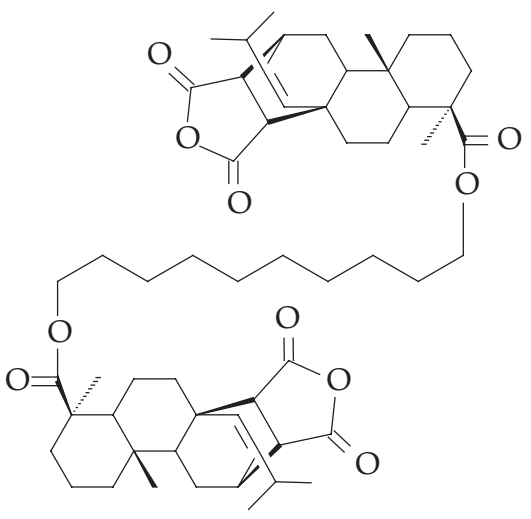

Decylene-1,10-dimaleopimarate (DDR)

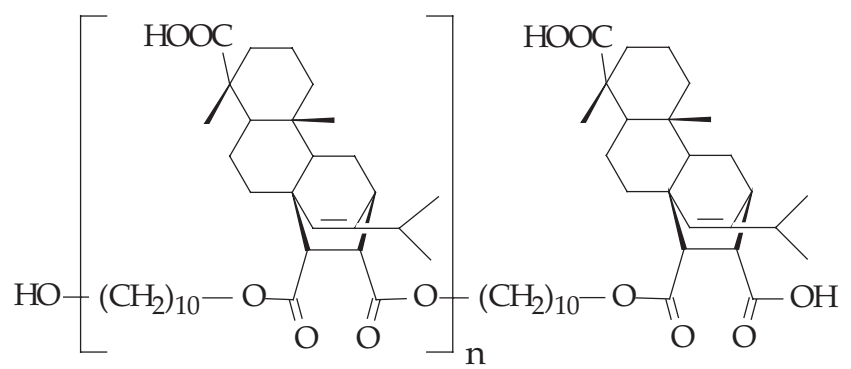

Poly(decylene maleopimarate) (PRD)

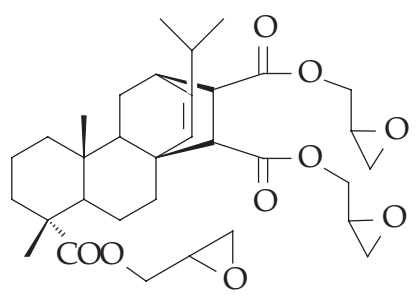

Triglycidyl maleopimarate (3GR)

Fig. 1. Schemes of rosin derivatives used in this work as coating components 
with 8-hydroxyquinoline, pearl white anticorrosive filler, specific surface $17 \mathrm{~m}^{2} \cdot \mathrm{g}^{-1}$, average lumen inner diameter $21 \mathrm{~nm}$, average particle diameter $250 \mathrm{~nm}$, prepared in a process described in our previous work [32]. Rutile grade titanium dioxide, commercial white pigment, average particle diameter 300 nm (R003, Grupa Azoty Police, Poland). Zinc phosphate, analytical grade, as a white pigment, fraction of particle diameter $<30 \mu \mathrm{m}$ (Merck, Germany). Commercial polyester zinc anti-corrosive powder paint (RAL7031 P/S1/U/97, Venice Int., Poland).

\section{Sample preparation}

Powder coating compositions were obtained as follows. Rosin-derived components were ground into fine powders using a knife mill. Next, they were mechanically pre-mixed in stoichiometric proportions (optionally in presence of $2.5 \mathrm{wt} \%$ of filler, $5 \mathrm{wt} \%$ of titania and $10 \mathrm{wt} \%$ of zinc phosphate) before extrusion via twin-screw $(16 \mathrm{~mm}, 1 / \mathrm{d}=40)$ co-rotating extruder Prism 16 (ThermoFisher, USA) at $120^{\circ} \mathrm{C}, 60 \mathrm{rpm}$. After cooling under ambient conditions the extrudate was ground by knife milling (1000 rpm) and classified using a sieve shaker. A fraction of 45-65 $\mu \mathrm{m}$ was loaded to Optiflex-2 corona-charging gun (Gema, Switzerland), applied uniformly onto steel substrates, and then cured in an oven at $200^{\circ} \mathrm{C}$ for $45 \mathrm{~min}$. The measured coatings thickness was $150 \pm 15 \mu \mathrm{m}$. The acronyms and composition of prepared coatings were presented in Table 1.

\section{Methods}

Rheological measurements of coating compositions were performed using DHR-1 rheometer equipped with Environmental Test Chamber and $25 \mathrm{~mm}$ plate-plate measuring system (TA Instruments, USA), gap $1 \mathrm{~mm}$, heating from 90 to $200^{\circ} \mathrm{C}$ (heating rate $10^{\circ} \mathrm{C} \cdot \mathrm{min}^{-1}$ ) followed by the reaction under isothermal conditions. Differential scanning calorimetry (DSC) was performed on a Q100 device (TA Instruments, USA). 9-13 mg samples were heated from 25 to $240^{\circ} \mathrm{C}$ with a heating rate of $10^{\circ} \mathrm{C} \cdot \mathrm{min}^{-1}$, standard aluminum pans were used under nitrogen atmosphere $25 \mathrm{~cm}^{3} \cdot \mathrm{min}^{-1}$. Thermogravimetric analysis (TGA) of cured coatings was carried out on a Q5000 device (TA Instruments, USA) in a platinum crucible. Samples between 5-10 mg were heated from 25 to $1000^{\circ} \mathrm{C}$ with a heating rate of $10^{\circ} \mathrm{C} \cdot \mathrm{min}^{-1}$, under air atmosphere, flow rate: air $25 \mathrm{~cm}^{3} \cdot \mathrm{min}^{-1}$, nitrogen (as protective gas) $10 \mathrm{~cm}^{3} \cdot \mathrm{min}^{-1}$. Ultraviolet-Visible Spectroscopy (UVVis) was done using UV9000s device (Biosens, Poland) for determination of coatings color of samples on $5 \times 5 \mathrm{~cm}$ substrates. Gloss of coatings at $20^{\circ} \mathrm{C}$ was determined using IQ20/60/85 device (Rhopoint Instruments, UK), in compliance with the ISO 2813 standard, 5 measurements were made. Hardness of coatings was tested using AWS-5 König pendulum (Dozafil, Poland), $20^{\circ} \mathrm{C}, 50 \%$ of relative humidity, 5 measurements were performed. G)
Adhesion of coatings to steel was checked in cross-cut test, according to EN ISO 2409 standard, 3 measurements were done. Cupping resistance (ISO 1520) of coatings on steel was determined using Model 200 cupping tester (Erichsen, Germany), 3 measurements were conducted. I) Chemical resistance to methyl ethyl ketone (MEK) was investigated in rubbing test, according to EN 13523-11 standard, 3 measurements were made. Performance in the salt chamber was carried out according to PN-EN ISO 9227:2007 in CorrosionBox 400 (Co.Fo.Me.Gra., Italy) using an aqueous $\mathrm{NaCl}$ solution (concentration of $50 \pm 5 \mathrm{~g} \cdot \mathrm{dm}^{-3}$ ) sprayed with compressed oil-free air $(100 \mathrm{kPa})$. The backside and edges of steel QD-46 Q-panels (dimensions: $102 \times 152 \mathrm{~mm}$ ) with $\mathrm{X}$-scratched coatings (according to EN ISO 17872:2007) were protected with a dedicated pressure adhesive tape (Tesa, USA) and mounted at an angle of $20^{\circ}$ vertically. The temperature in a spray cabinet was maintained at $35^{\circ} \mathrm{C}$ during the test period of 500 hours.

\section{RESULTS AND DISCUSSION}

\section{Content of natural resources and thermal properties of coating materials}

The investigation of thermal properties of coatings were performed in order to evaluate cross-linking behavior, cross-linking density, thermal stability and glass transition temperature of obtained materials.

The results of prepared coatings curing process investigation were shown in Fig. 2. The curves included heat up from 90 to $200^{\circ} \mathrm{C}$ (for 11 minutes) were followed by the reaction under isothermal conditions. Reference samples were marked in grey. As can be seen in Fig. 2a, the addition of pigments to varnish DDR/3GR [30] hardly influenced the curing process. Similarly, but slightly more visible difference between DDR/3GR/H [31] varnish and $\mathrm{DDR} / 3 \mathrm{GR} / \mathrm{H} / \mathrm{P}$ prototype paint could be observed, i.e. lower slope of pigmented composition in the first $15 \mathrm{~min}$ utes of curing process. The mentioned difference in early stage cross-linking was also observable for PRD-based compositions (Fig. 2b), but after 30 minutes, the viscosity of pigmented and reference samples reached out the same level. What is particularly important, the formulation of paint prototypes, i.e. the addition of non-reactive pigments, did not negatively affected the good regularity of reference binders cross-linking behavior.

The next parameter determined in this study was thermal stability of prepared samples. Fig. 3 showed its values in function of natural resources content in coatings. This content varied from $0 \%$ for COMM petroleum-based reference to ca. $82 \%$ for rosin-based varnishes. Natural resources content in obtained prototype paints was ca. $75 \%$ because of the presence of chemical-origin pigments. Values of thermal stability were defined as temperature at $5 \%$ mass loss $\left(T_{5 \%}\right)$. It could be easily found, that rosinbased coatings showed significantly better thermal stabil- 

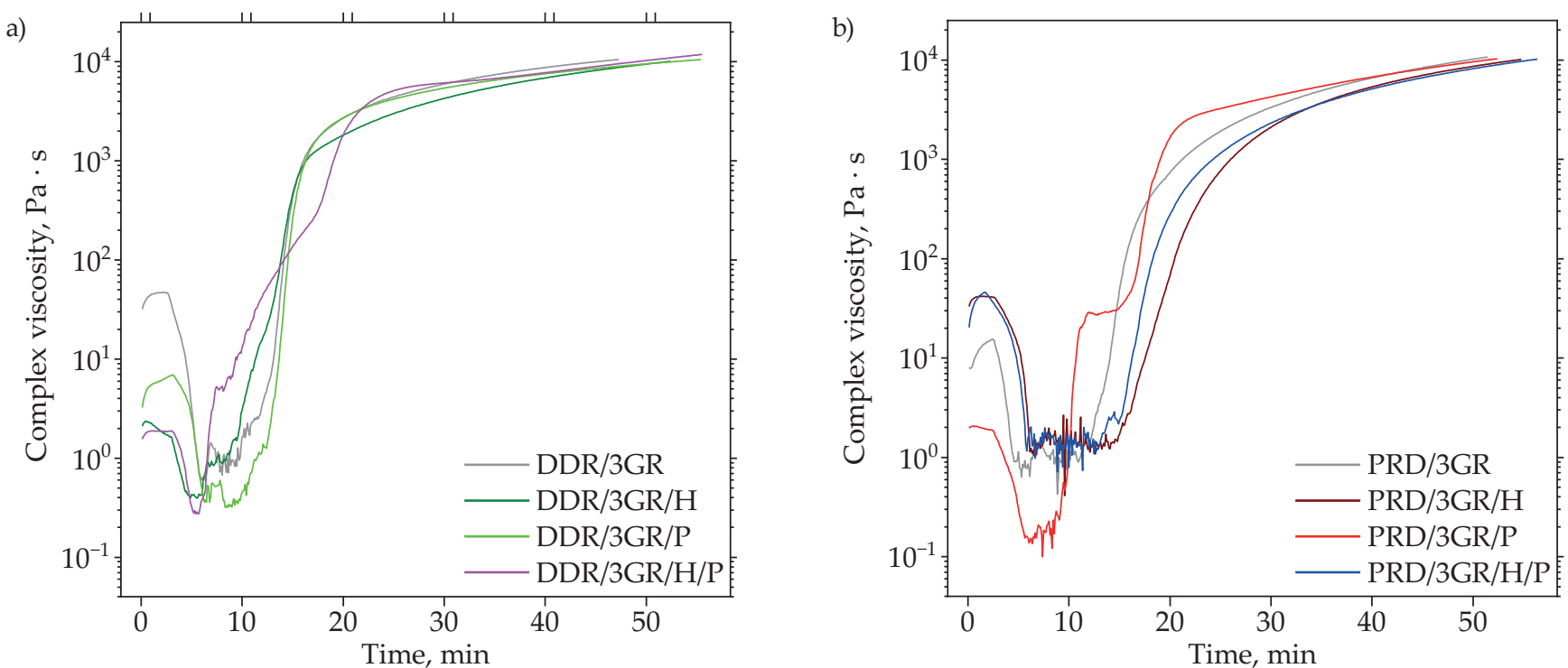

Fig. 2. Rheological curves of coating composition curing processes. Reference samples marked in grey

ity than petroleum-based reference. Moreover, $T_{5 \%}$ values of rosin paints were noticeably higher (up to $370^{\circ} \mathrm{C}$ ), than those of rosin varnishes, but this difference could result from the higher content of non-degradable inorganic mass of pigments. It is noteworthy, that the same dependence could be observed for the samples with halloysite filler. High thermal stability of rosin-sourced materials was also confirmed by others [19]. It may be preliminary concluded, that a higher molar mass of rosin-based dianhydride can improve the thermal stability of samples.

Values of glass transition temperature $\left(T_{q}\right)$ were also presented in Fig. 3 in the same way as $T_{5 \%} . T_{g}^{8}$ of COMM sample reached ca. $90^{\circ} \mathrm{C}$, while $T_{g}$ of rosin-based samples was noticeably higher and varied in a very narrow range near $100^{\circ} \mathrm{C}$. Such results confirmed good cross-linking

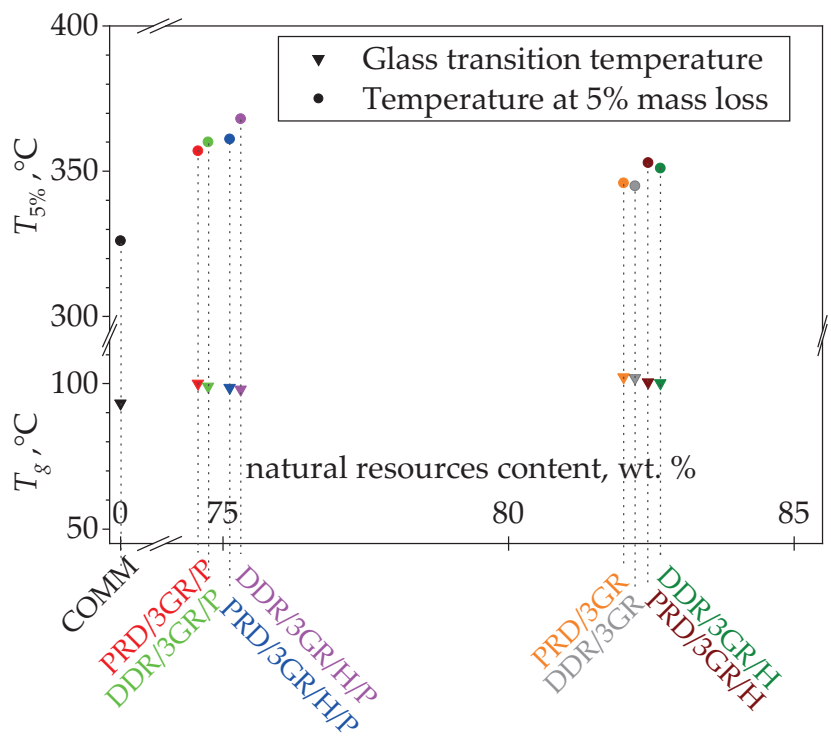

Fig. 3. Content of natural resources in prepared coatings and reference samples and their values of glass transition temperature $\left(T_{g}\right)$ and temperature at $5 \%$ mass loss $\left(T_{5 \%}\right)$. Sample symbols are explained in Table 1 degree of the polymer matrix of rosin-based samples, that was not deteriorated by the presence of additions.

\section{Mechanical and functional properties of coatings}

The investigation of functional and mechanical features of prepared materials included such parameters, that are the most important from a user point of view. They can be summarized as a physical endurance to various mechanical factors, resistance in chemically aggressive environment and defined outlook.

The results of hardness tests were shown in Fig. 4. The obtained coatings exhibited high values of this parameter (in a range of 201-210 a.u.) that were similar to rosinbased reference varnishes. Moreover, this value was higher than for COMM reference (182 a.u.) and not very much lower than for uncoated steel substrate (240 a.u.). It can be noticed, that hardness of DDR-type samples was slightly higher than PRD-type. On the other hand, there was not found a considerable impact of the inorganic particles presence on coatings hardness: the high values of this parameter probably resulted from properly crosslinked polymer matrix with built-in rigid diterpene structures of rosin acids.

Enhanced hardness of rosin-based samples went with their worse cupping resistance, in comparison with petroleum-based reference. As can be seen in Fig. 4, COMM sample showed higher cupping resistance $(9 \mathrm{~mm})$ than rosin-based prototype paints $(7,1-7,9 \mathrm{~mm})$. Nevertheless, such proportion of this parameter values remained acceptable for potential users. The presence of flexible 1,10-decylene chains in coatings structure led to obtaining hard, but moderately deformable materials. It should be noted, that cupping resistance of the prototype paints did not significantly differ from their rosin-based reference samples, however DDR-cured materials exhibited slightly better values of mentioned parameter than PRDtype samples. 


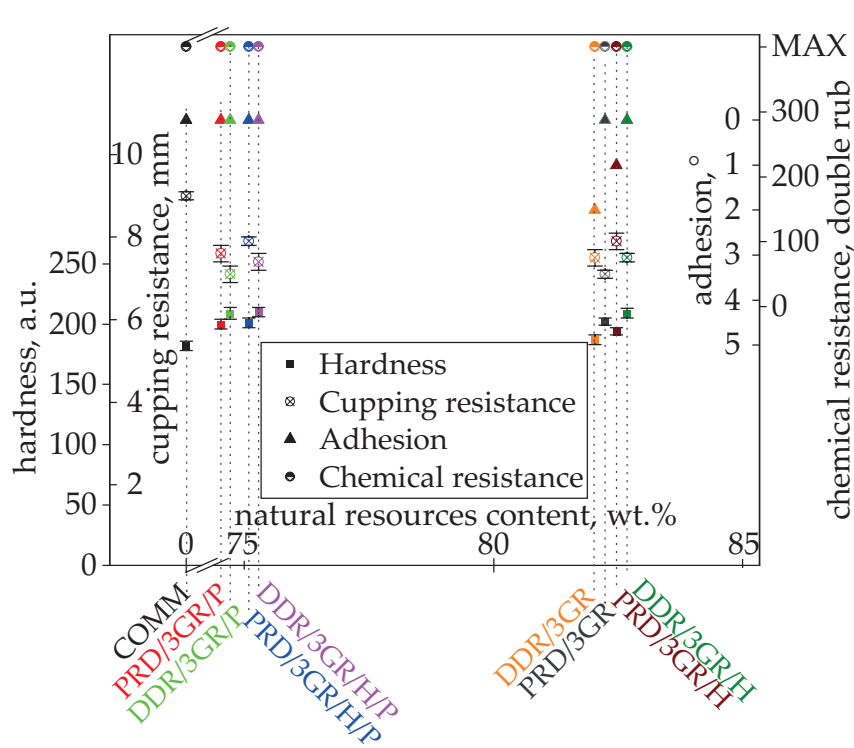

Fig. 4. Hardness, cupping resistance, adhesion and chemical resistance of prepared coatings and reference samples. Sample symbols are explained in Table 1

Adhesion of coatings to steel substrate (Fig. 4) was evaluated according to ISO 2409 in 6-degree scale, where $0^{\circ}$ means the best adhesion (no delamination after crosscut), and $5^{\circ}$ is the worst adhesion (delamination $>50 \%$ ). Both COMM petroleum-based paint and a group of 4 prototype rosin-based paints exhibited perfect adhesion to steel $\left(0^{\circ}\right)$. Interestingly, reference rosin varnishes showed rather diverse range of adhesion, from $0^{\circ}$ for DDR-type to $1-2^{\circ}$ for PRD-type samples. Therefore a preliminary conclusion can be formed, that the addition of inorganic pigments to PRD-based varnishes can improve their adhesion to steel. Probably this phenomenon can be attributed to the influence of inorganic particles on the relaxation of stresses in polymer matrix during crosslinking process.

Investigation of barrier properties against methylethyl ketone showed out the highest measurable chemical resistance of all prepared prototype coatings, same as for COMM reference. The highest chemical resistance was a criterion for the selection of coating compositions to obtain prototype paints, so in comparison with rosinbased references, this parameter was not deteriorated after addition of inorganic pigments. The results of chemical resistance were set in Fig. 4.

Interestingly, the results of corrosion resistance salt spray chamber test, which were presented in Fig. 5, turned out to be more varied. COMM sample represented anti-corrosive possibilities of commercial products after $500 \mathrm{~h}$ in salt chamber: visible rusty $\mathrm{X}$-scratch and slight trickles could be observed. Against this background, unfilled rosin-based reference varnishes (DDR/3GR and PRD/3GR) showed stronger rusting of $X$-scratch and trickling; especially PRD/3GR sample, that were characterized by the weakest adhesion in this study (Fig. 4). The introduction of modified halloysite was beneficial to anticorrosive performance of these references $[30,31]$ rusting and trickling on DDR/3GR/H and PRD/3GR/H samples were less visible.

Better anti-corrosive properties of DDR/3GR matrix were confirmed by protective performance of prepared prototype paints. DDR/3GR/P and DDR/3GR/P/H paints had very good protective properties with no visible rusting of X-scratch (Fig. 5). On the other hand, PRD/3GR/P and $\mathrm{PRD} / 3 \mathrm{GR} / \mathrm{P} / \mathrm{H}$ prototypes presented anti-corrosive performance similar to COMM reference, with visible rusting and trickles. It could be seen, that $\mathrm{PRD} / 3 \mathrm{GR} / \mathrm{P} / \mathrm{H}$ showed slightly better performance than PRD/3GR/P thanks to aforementioned beneficial influence of halloysite filler. In conclusion, the composition of rosin-based varnishes with the inorganic pigments significantly improved their corrosion protection of steel.

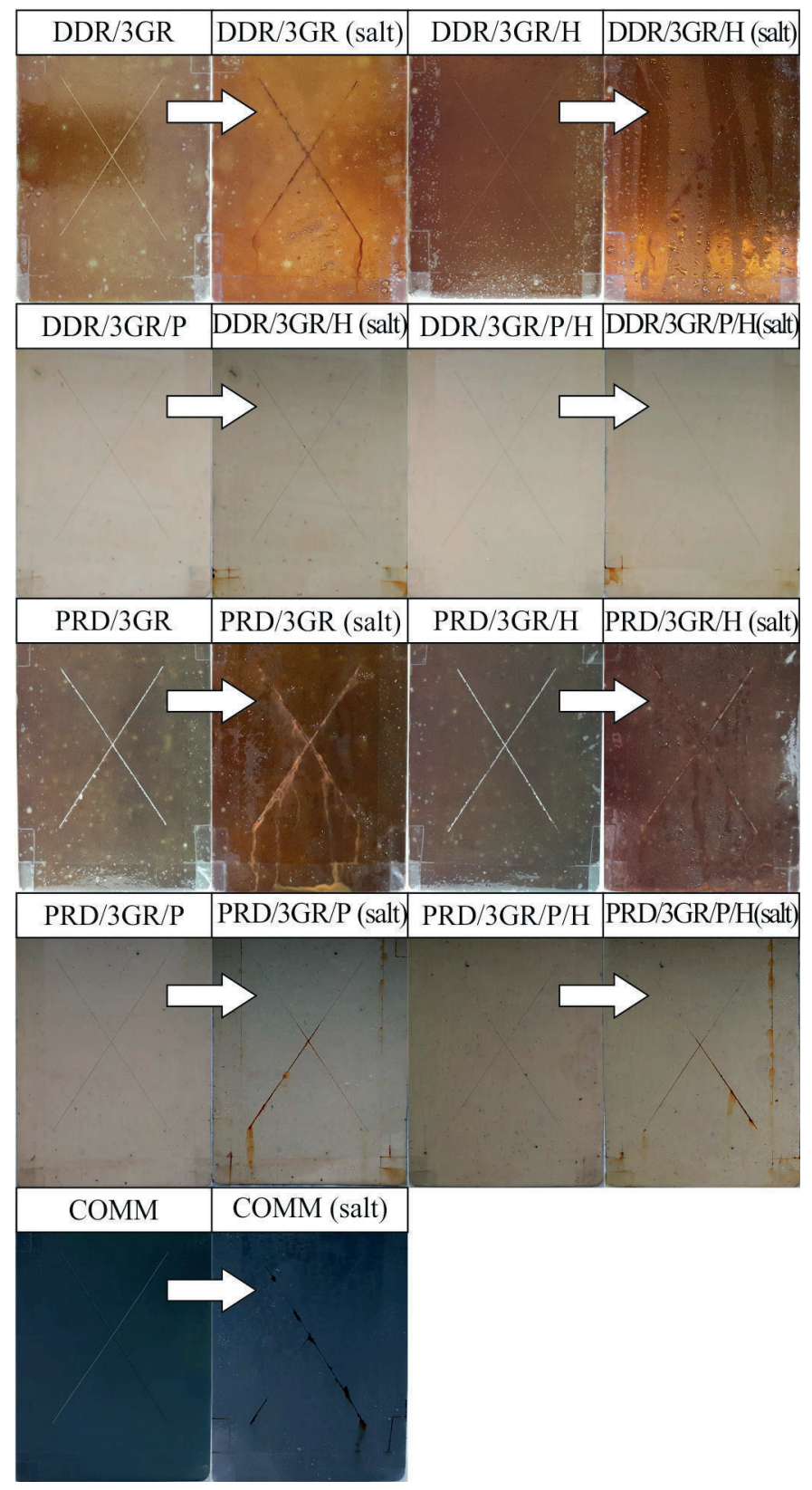

Fig. 5. Prepared coatings and reference samples before and after $500 \mathrm{~h}$ of salt spray test 
From a user point of view, visual properties of paints are particularly important. As can be seen in Table 2, the addition of pigments successfully brightened the original, rather dark colors of rosin-based varnishes. Furthermore, gloss of prototype paints (23-26 G.U.) was significantly lower than reference rosin-based varnishes (51-66 G.U.). These proved the possibility of modification of rosin-based coatings visual properties towards the brighter and less shiny materials.

$\mathrm{T}$ a b 1 e 2. Visual properties of prepared coatings and reference samples

\begin{tabular}{c|c|c}
\hline Sample symbol & Gloss (G.U.) & Color (RAL) \\
\hline DDR/3GR & $66 \pm 4$ & 6013 (red green) \\
DDR/3GR/H & $65 \pm 2$ & 1019 (grey beige) \\
DDR/3GR/P & $26 \pm 2$ & 7030 (stone grey) \\
DDR/3GR/H/P & $24 \pm 1$ & 7030 (stone grey) \\
PRD/3GR & $52 \pm 3$ & 8025 (pale brown) \\
PRD/3GR/H & $51 \pm 2$ & 7006 (beige grey) \\
PRD/3GR/P & $23 \pm 2$ & 7005 (mouse grey) \\
PRD/3GR/H/P & $23 \pm 2$ & 7039 (quartz grey) \\
COMM & $57 \pm 2$ & 7031 (blue grey) \\
\hline
\end{tabular}

\section{CONCLUSIONS}

Two recently prepared rosin-based coating systems were developed to obtain working prototypes of ecological protective paints with natural resources content of ca. $75 \mathrm{wt}$ $\%$ and cross-linking kinetics appropriate for powder coating applications. Advantageously, they were characterized by higher thermal stability, glass transition temperature, hardness and anti-corrosive performance than petroleumbased reference, as well as much brighter color than rosin derivatives. On the other hand, they exhibited noticeably lower, but acceptable for the users cupping resistance and gloss. Coating system based on decylene-1,10-dimaleopimarate and triglycidyl maleopimarate showed better properties (especially corrosion protection) than materials from poly(decylene maleopimarate), so it should be a subject of scaling-up in the industry. Finally, this study is a prove, that naturally-sourced coating materials can replace petroleum-based counterparts, even in such demanding application, as corrosion protection of steel.

\section{ACKNOWLEDGEMENTS}

This work was financially supported by National Centre for Research and Development (project no. LIDER/7/0045/L-8/16/ NCBR/2017).

\section{REFERENCES}

[1] Global Paint \& Coatings 7th edition. Available online: https://www.freedoniagroup.com/industry-study/ global-paint-coatings-4043.htm (accessed on Feb 1, 2021)
[2] Geyer R.: "Plastic Waste and Recycling", (red. Letcher T.), Academic Press, Cambridge 2020; p. 13

[3] Ritchie H., Roser M.: Our World in Data, 2020, https://ourworldindata.org/ (accessed on Feb 1, 2021)

[4] Powder Coatings Market Size, Share Industry Report 2027, Available online:

https://www.grandviewresearch.com/industry-analysis/powder-coatings-market-analysis (accessed on Feb 1, 2021)

[5] Spyrou E.: "Powder Coatings Chemistry and Technology: 3rd Revised Edition", Vincentz Network, Hannover 2014

[6] Ma S., Li T., Liu X. et al.: Polymer International, 2016, 65,164 . https://doi.org/10.1002/pi.5027

[7] Ding, C., Matharu A.S.: ACS Sustainable Chemistry \& Engineering, 2014, 2, 2217.

https://doi.org/10.1021/sc500478f

[8] Kumar S., Samal S.K., Mohanty S. et al.: PolymerPlastics Technology and Engineering, 2018, 57, 133. https://doi.org/10.1080/03602559.2016.1253742

[9] Baroncini E.A., Yadav S.K., Palmese G.R. et al.: Journal of Applied Polymer Science, 2016, 133, 44103. https://doi.org/10.1002/app.44103

[10] Kumar S., Krishnan S., Mohanty S. et al.: Polymer International, 2018, 67, 815. https://doi.org/10.1002/pi.5575

[11] Kugler S., Ossowicz P., Malarczyk-Matusiak K. et al.: Molecules, 2019, 24, 1651. https://doi.org/10.3390/molecules24091651

[12] Lu Y.J., Xu R.S., Zhao Z.D. et al.: Advanced Materials Research, 2013, 785-786, 1111. https://doi.org/10.4028/www.scientific.net/AMR.785786.1111

[13] Parthiban A.: "Synthesis and Applications of Copolymers", Wiley-Blackwell, Hoboken 2014, p. 101

[14] Gandini A., Lacerda T.M.: Progress in Polymer Science, 2015, 48, 1. https://doi.org/10.1016/j.progpolymsci.2014.11.002

[15] Zia K.M., Noreen A., Zuber M. et al.: International Journal of Biological Macromolecules, 2016, 82, 1028. https://doi.org/10.1016/j.ijbiomac.2015.10.040

[16] Wilbon P.A., Chu F., Tang C.: Macromolecular Rapid Communications, 2013, 34, 8. https://doi.org/10.1002/marc.201200513

[17] Liu X., Xin W., Zhang J.: Green Chemistry, 2009, 11, 1018. https://doi.org/10.1039/B903955D

[18] Liu X., Xin W., Zhang J.: Bioresource Technology, 2010, $101,2520$. https://doi.org/10.1016/j.biortech.2009.11.028

[19] Wang H., Liu X., Liu B. et al.: Polymer International, 2009, 58, 1435. https://doi.org/10.1002/pi.2680

[20] Mustata F.R., Tudorachi N.: Industrial \& Engineering Chemistry Research, 2010, 49, 12414. https://doi.org/10.1021/ie101746v 
[21] Liu X.Q., Huang W., Jiang Y.H. et al.: Express Polymer Letters, 2012, 6, 293. https://doi.org/10.3144/expresspolymlett.2012.32

[22] Liu X., Zhang J.: Polymer International, 2010, 59, 607. https://doi.org/10.1002/pi.2781

[23] Jaswal S., Gaur B.: Polymer Science Series B, 2015, 57, 417. https://doi.org/10.1134/S1560090415050048

[24] Li T., Liu X., Jiang Y. et al.: Iranian Polymer Journal, 2016, 25, 957. https://doi.org/10.1007/s13726-016-0482-0

[25] Deng L., Shen M., Yu J. et al.: Industrial \& Engineering Chemistry Research, 2012, 51, 8178. https://doi.org/10.1021/ie201364q

[26] Li C., Liu X., Zhu J. et al.: Journal of Macromolecular Science, Part A, 2013, 50, 321. https://doi.org/10.1080/10601325.2013.755879

[27] El-Ghazawy R.A., El-Saeed A.M., Al-Shafey H.I. et al.: European Polymer Journal, 2015, 69, 403. https://doi.org/10.1016/j.eurpolymj.2015.06.025

[28] Brocas A.-L., Llevot A., Mantzaridis C. et al.: Designed Monomers and Polymers, 2014, 17, 301. https://doi.org/10.1080/15685551.2013.840504

[29] Mantzaridis, C., Brocas, A.-L., Llevot, A. et al.: Green Chemistry, 2013, 15, 3091. https://doi.org/10.1039/C3GC41004H

[30] Kugler, S., Ossowicz-Rupniewska, P., Wierzbicka E. et al.: Coatings, 2021, 11, 531. https://doi.org/10.3390/coatings11050531

[31] Kugler, S., Wierzbicka, E., Ossowicz-Rupniewska, P. et al.: Polymers, 2021, 13, 1700. https://doi.org/10.3390/polym13111700

[32] Wierzbicka, E., Kugler, S., Ossowicz, P. et al.: Materials Engineering, 2020, 5. https://doi.org/10.15199/28.2020.5.2

Received 15 VI 2021 